\title{
Editorial
}

\section{Las inversiones de la realidad y el falso realismo pragmático}

A menudo se efectúa una lectura de la realidad en forma invertida, tal fenómeno se constituye entonces en una mistificación de la realidad.

Tal mistificación de la realidad al ser interiorizada por los sujetos deriva en una ideologización que pretende sustituir a la realidad misma. Las representaciones ideologizadas reclaman para si el statu de verdad absoluta en sí y por sí misma y no admiten una reflexión ulterior que pudiera evidenciar la falsedad o realidad de sus planteamientos.

Las cosas son asi y es preciso actuar de conformidad con ellas, con lo cual se avanza hacia un pretendido realismo que es la negación de la realidad misma. Llegando de esta manera a constituirse en un pseudo realismo pragmático que decide lo que es factible y lo que no es factible. La verdad sólo puede ser lo que inmediatamente se ve como posible y sólo es posible lo que está conforme con la representación ideologizada de la realidad. Poco importa ya, cuál sea la verdadera realidad, ésta ha sido plenamente sustituida por las representaciones mistificadas que adquieren la fuerza de un prejuicio popular.

La razón esencial que busca dar cuenta de la verdadera realidad, por el contrario, es tildada de ilusoria, de poco o nada práctica y rechazada por considerarla como meros juicios de valor o fruto de una ideologia que busca subvertir el statu quo muy de acuerdo con el "realismo pragmático". $Y$ es que el "realismo pragmático" se fundamenta y busca dar continuidad al sistema social establecido, de alli que al cuestionarlo se cuestione necesariamente un determinado orden social que responde a ciertos grupos sociales cuyos intereses económicos y, consecuentemente, sus intereses políticos están en contradicción con el resto de la 
sociedad.

El "realismo pragmático" adquiere su fuerza en ol llamado sentido común en tanto que es mucho más fácil asimilar la realidad aparencial que la realidad esencial, esta última exige un ejercicio de la razón, desentranar lo oculto, ir a la raíz de las cosas, liberarse de las mistificaciones y optar por el interés social, esto es, los intereses reales de las mayorías populares, los cuales deben de constituir el criterio de objetividad social e histórico. El por qué ello tiene que ser asi, obedece a varias razones entre las cuales destacan: primero, el hecho de que los intereses de las minorías al estar en contradicción con los de las mayorías exige mistificar la realidad, ya que de esa manera se encubre la verdadera realidad y se busca a la vez justificar un detemirnado statu quo irracional e injusto; segundo, porque los intereses reales de las mayorias populares para poder ser alcanzados exigen el conocimiento verdadero de la realidad, esto es, traspasar el nivel de lo fenoménico $\theta$ ir a su esencialidad; tercero, por que to que está en juego para las mayorlas populares es una realidad de vida o muerte, de alli que la defensa de sus intereses se presenta como una exigencia histórica de cara a existir como sociedad humana.

Solamente contrastando la pretendida verdad del realismo pragmático con los intereses reales de las mayorías populares es que podemos desenmascarar la falsedad de sus planteamientos y, a su vez, nos permite conocer con certeza qué líneas o corrientes de pensamiento buscan tan sólo conservar una determinada organización social que es en su naturaleza excluyente y marginadora de las mayorlas.

El realismo pragmático ha hecho presa en sus redes de to factible, a muchos intelectuales bien intencionados que no estarian dispuestos a optar en forma consciente por los intereses económicos y políticos de las minorias privilegiadas, en contra del bienestar social de las mayorlas, pero que, sin embargo, han sido persuadidos por la factibilidad lógica, sin detenerse a considerar que lo lógico no es sinónimo de real.

Parece lógicamente imposible, aquí y ahora, la factibilidad histórica de una nueva forma de organización social, por tanto, ello es irreal. Sin embargo, lograr el bienestar social para las mayorías populares reclama una nueva forma de organización social con toda la exigencia que pueda hacer la historia. Nos parece que el desarrollo social no se rige por la lógica formal sino por la lógica histórica. 